\title{
N-Terminal ProB-type Natriuretic Peptide Measurement
}

National Cancer Institute

\section{Source}

National Cancer Institute. N-Terminal ProB-type Natriuretic Peptide Measurement. NCI Thesaurus. Code C96610.

The determination of the amount of $\mathrm{N}$-terminal proB-type natriuretic peptide present in a sample. 